\title{
Life cycle assessment analysis of kenaf cultivation in bonorowo land, laren, lamongan
}

\section{Desrina Yusi Irawati*, Lusi Mei Cahya Wulandari}

Department of Industrial Engineering, Faculty of Engineering, Universitas Katolik Darma Cendika, Jl. Dr. Ir. H. Soekarno No.201, Surabaya, Jawa Timur, 60117, Indonesia

\begin{tabular}{l} 
ARTICLE INFORMATION \\
\hline Article history: \\
Received: July 18, 2019 \\
Revised: November 19, 2019 \\
Accepted: November 25, 2019 \\
\hline
\end{tabular}

Keywords:

Kenaf Cultivation

Life Cycle Assessment (LCA)

Environmental Impact

\section{A B S T R A C T}

The largest kenaf culture in Indonesia is in Laren, Lamongan. Kenaf plants are suitable to be planted in the Bonorowo field. The less potential land conditions make the cultivation of kenaf plants must use chemicals. The use of chemicals has the potential to harm the environment. The approach to identifying and analyzing environmental impacts is the Life Cycle Assessment (LCA). LCA is one method to find out the life cycle of agriculture. LCA stages are Goal and Scope Definition, Life Cycle Inventory, Life Cycle Impact Assessment, and Interpretation. Environmental impact measurement is based on fifteen categories grouped into four categories. LCA processing results show the use of urea fertilizer has the most significant negative impact on the environment. The biggest impact category due to the use of urea fertilizer is aquatic ecotoxicity. The use of urea fertilizer affects the types of resources, climate change, ecosystem quality, and human health. Of the four groups, which have the highest value, are the resource group. The use of urea fertilizer has the most significant role in the success of kenaf cultivation because kenaf cultivation requires more $\mathrm{N}$ elements to improve the quality of kenaf stems. The use of organic fertilizer can be an option to reduce the use of urea fertilizer.

This is an open-access article under the CC-BY-NC-SA license.

*Corresponding Author

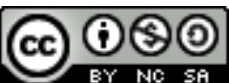

\section{INTRODUCTION}

Biodiversity, vast land, and tropical climate make Indonesia has a great potential to improve aspects of agriculture or plantations compared to other countries. One of the plantation products that are the mainstay of several regions in Indonesia is kenaf plantation. Kenaf (Hibiscus cannabinus L.) is a quality plant that produces fiber for industries with high economic value. Based on information from farm Bonorowo Land, the largest kenaf plantation in Indonesia is in the Lamongan area, covering an area of 2,150 hectares.

The steps of the kenaf cultivation process are planting, maintaining, and harvesting. Planting is done by spreading kenaf seeds intercropped with maize or rice plant. Maintenance consists of fertilizing, thinning, and pest control. Harvesting is done if $50 \%$ of the kenaf plants flowering. Harvesting is done by cutting the base of the stem just above the soil surface. After the kenaf stem is 
cut, the stem is immersed for 14-20 days. The soaked stem is then made fibrous to separate the skin from the kenaf stem. Washed kenaf fibers are placed on a para-para to dry in the sun [1]. Parapara is a bamboo rack used for storing goods.

One of the obstacles faced for developing kenaf commodities is low productivity at the farm level. Based on information from the coordinator of the farmer group in Bonorowo Land, Mr. Wikurlan, the average kenaf yield in 2018 was 1.478 tons/hectares. To break even, it requires productivity of 2 tons/hectare [2]. The main factors causing low productivity in kenaf agriculture are the availability of nutrients in the soil, and pests. Bonorowo Land generally has nutrients about modest $\mathrm{N}$-total, low $\mathrm{P}$, low $\mathrm{K}$, and $\mathrm{pH} 4-4,2$. Thus the Bonorowo Land has less to moderate fertility, so a balanced fertilizer application is needed [3]. The use of fertilizers adversely affects the survival cycle [4], [5], [6], and [7]. Agriculture is also inseparable from the use of insecticides to reduce the number of pests. However, excessive use of pesticides can also cause environmental problems around it.

Environmental problems arising from kenaf cultivation activities need to be identified so that further corrective steps can be taken. One approach to identifying and analyzing environmental impacts is the Life Cycle Assessment (LCA). LCA is one method for investigating the ecological impact of a production system throughout its life cycle [8]. The strength of LCA is that it provides a complete picture of products, processes, and services. LCA covers the production and consumption of resources such as energy or carbon emissions wherever the process is located. Small changes that bring environmental benefits can create more carbon emissions. LCA can evaluate any changes in the production timeline. The disadvantage of using the LCA method is that the data required is specific and needs a good inventory of data so that the pooling of data takes time and costs, the LCA process cannot determine the best or most cost-effective product or process [9].

LCA has been implemented to determine and manage environmental impacts in various production sectors such as industry, energy, and agriculture. LCA research on the plantation world has been carried out in several countries. LCA is used to discuss the environmental impact of peanut farming in Guilan, Iran. The study assessed six impact categories. The highest ecological impact is the depletion of fossil resources [10]. In South China, research has been conducted on the effects of integrated aquaculture farming using the LCA method. In his research results showed that the majority of the total global warming system (97\%) was associated with the use of methane from fertilized land [11].

Research related to the environmental impact on the agricultural sector in Iraq from 2007 to 2014 was carried out using the LCA method. The calculated impact categories are global warming impacts, potential acidification, and terrestrial eutrophication. The result is that from 2014 to 2017, the adverse effects of terrestrial eutrophication has the most considerable influence on the environment [12]. Environmental impact analysis with LCA was also carried out for the agrosystem model planting system. Environmental impacts considered are increasing energy use, global warming, eutrophication potential, and acidification [13]. In 2019 there will be LCA research on cucumber and tomato farming in open fields and greenhouses. The results show that of the overall impact, greenhouse cucumber farming is more environmentally friendly than greenhouse tomato farming. The most significant contribution to the impact category is caused by the use of electricity and fertilizer [14]. Previous studies discuss rice farming in Iran. In his research, the focus of the analysis is the impact of the use of fertilizers for several types of rice grown using LCA. The impact categories to be analyzed are global warming, acidification, terrestrial eutrophication, depletion of fossil, phosphate, and potassium resources [15].

So far, research on kenaf has only been limited to a few topics, mainly only about the use and benefits of kenaf fiber. Previous studies related to LCA and kenaf are research on the benefits and sacrifices of implementing bio-based materials (kenaf fiber) in the field of automotive component production and environmental impact analysis from the use of kenaf core in structural insulation panels [16], [17]. Based on the results of the summaries of 2014 to 2019 related to the use of LCA in agriculture, there are no studies on LCA in kenaf cultivation [18]. Research on environmental aspects of kenaf agriculture has 
been carried out in Bangladesh and Portugal. In that study, the most significant environmental impact of kenaf agriculture in Bangladesh was the effects of global warming, nutrition, human toxicity, and chemical oxygen pollution. The ecological implications of kenaf agriculture in Portugal is the emission of acidification [19], [20]. Each region and system of agricultural implementation will produce different results.

This study discusses the environmental impacts of kenaf cultivation in Bonorowo Land, Laren, Lamongan by using the LCA method. The focus of this research is to consider fifteen ecological impact categories. The fifteen types of impacts are non-renewable energy, mineral extraction, global warming, aquatic ecotoxicity, terrestrial ecotoxicity, aquatic acidification, aquatic eutrophication, terrestrial acid/nutrients, land occupation, carcinogens, respiratory inorganics, respiratory organics, ionizing radiation, ozone layer depletion, non-carcinogens [21].

\section{RESEARCH METHODS}

This research uses secondary data. Overall, data from kenaf cultivation was obtained from the farming business group. All data are collected from September 2018 to February 2019, according to the age of kenaf cultivation. They are starting from the distribution of seeds to kenaf fiber delivery to collectors. Data collected included information on the characteristics of kenaf plants, the area of kenaf cultivation land, inputs of the kenaf cultivation process, fertilizer and insecticide content, types of fertilizers and pesticides, the amount of kenaf fiber yield, and the distribution of kenaf fiber from planting to collectors. Data is processed using the LCA method with four main steps [22]. The flow of this research is shown in Fig. 1.

\section{Goal and Scope Definition}

The purpose of this study was to analyze the environmental impact of the kenaf cultivation process in Bonorowo Land, Laren, Lamongan. Cultivation that is calculated starting from the spread of seeds to kenaf fiber is distributed to collectors. The functional unit is $1 \mathrm{~kg}$ of kenaf fiber.

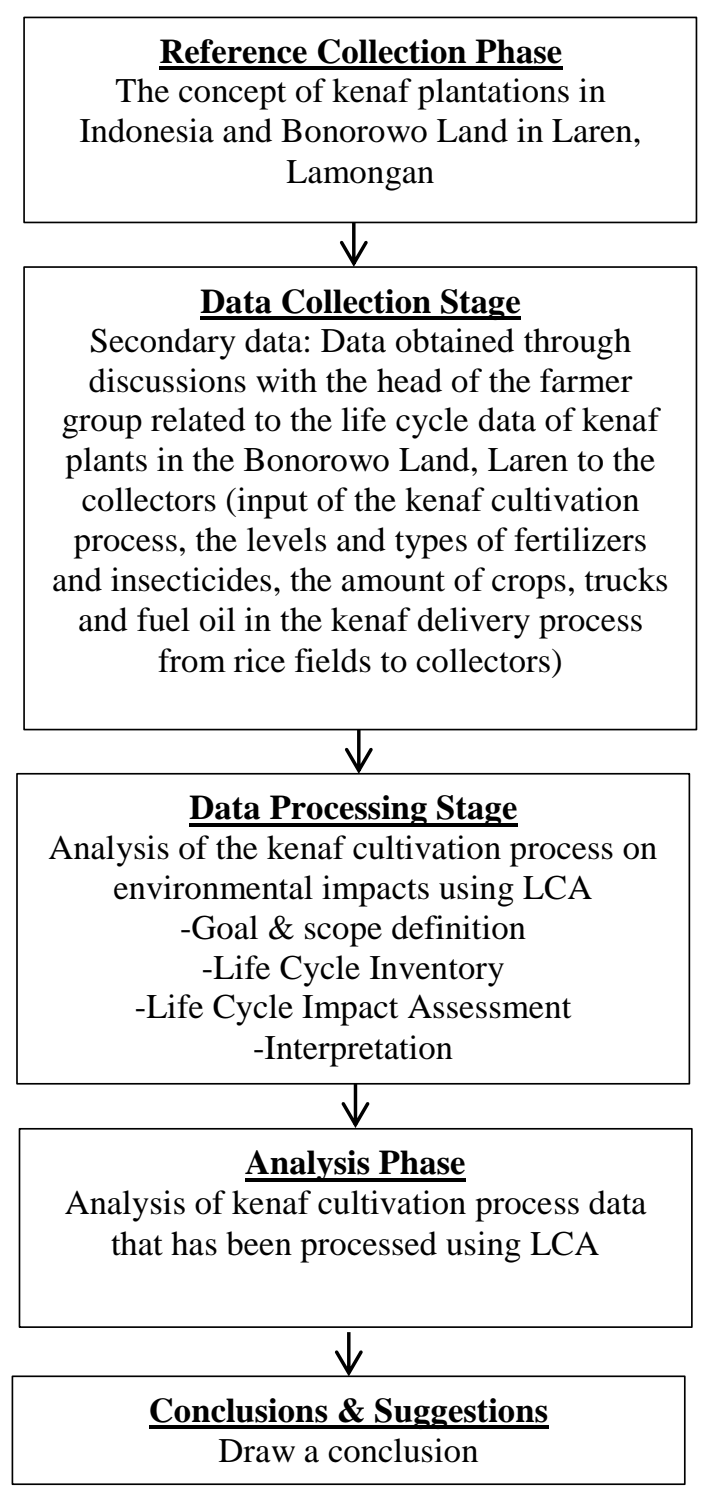

Fig. 1. Research flow

\section{Inventory Analysis}

At this stage, all resource and waste consumption data are collected in the kenaf aquaculture process. Data collection is based on direct observation in the field and through interviews with the head of the farmer.

\section{Impact Assessment}

Impact assessment consists of the characterization and normalization stages. At the characterization stage, there are fourteen impact categories to be analyzed. The fifteen impacts are part of the 2002+ Impact method. The characterization index is calculated through the coefficients of each pollutant in the impact category. To get the 
normalization index in the impact category calculated by dividing the value of the characterization of the impact category by the normalization factor in the impact category [15].

\section{Interpretation}

From the results of data processing on environmental aspects using the LCA method, the most significant environmental impact information will be obtained from kenaf cultivation in Bonorowo Land, Laren, Lamongan.

\section{RESULTS AND DISCUSSION}

99\% of kenaf has planted in Indonesia in Laren village, Lamongan. The planting period for kenaf is six months, starting from September to February. Every year the planting area is between 1,000-2,000 hectares. However, for planting in September 2018 until February 2019, only 676.5 hectares of land were used. The kenaf cultivation process consists of sowing, fertilizing, caring, harvesting, soaking and absorbing, and transporting.

The process of planting kenaf on Bonorowo Land, Laren, is different from the planting of most estate crops. Kenaf cultivation is seasonal. During not planting, kenaf farmers use Bonorowo Land to grow rice. The initial stage of sowing kenaf seeds, seedlings spread for 7 to 10 days before the rice harvest period. Kenaf seeds are allowed to grow wild. During the growth process, kenaf plants must be fertilized and sprayed with insecticides. The fertilizer used is urea fertilizer, $321,000 \mathrm{~kg}$ during the cultivation period. Spraying pesticides is part of the treatment. The poison is sprayed on kenaf leaves and stems. The insecticide used in planting kenaf contains chlorpyrifos active ingredients that function to disable and kill insect pests, such as leaf caterpillars, armyworms, lice, flies, and so forth. Chlorpyrifos is a non-systemic organophosphate class of insecticides that works when in contact with skin, is inedible, and is inhaled [23]. During the kenaf planting period, a pesticide used was 265 liters with chlorpyrifos content of $200 \mathrm{~g} / \mathrm{l}$. The traditional planting process, the distribution of seeds to harvest kenaf fiber relies on human labor. Before harvesting kenaf fiber, the fiber stem must be immersed in water for 2 to 3 weeks. Soaking the kenaf stem using rainwater and drying the kenaf fiber utilizing the sun's heat. Delivery of kenaf fibers to collectors using trucks with a distance of $27 \mathrm{~km}$.

All data were obtained from information from the Head of Kenaf Cultivation. Furthermore, the data is processed by the LCA method. SimaPro 9 software is a tool in processing LCA data. When data is processed using SimaPro 9, all data entered in the Life Cycle Inventory cycle. Input data until the results of crop cultivation are written in Table 1. The data in Table 1 are processed with the stages of characterization and normalization following environmental considerations arising from kenaf cultivation.

Table 1. The input and output data of kenaf cultivation for 6 months

\begin{tabular}{lll}
\hline $\begin{array}{l}\text { Product } \\
\text { output }\end{array}$ & Kenaf fiber & $\begin{array}{l}\mathbf{1 , 0 0 0} \\
\text { tons }\end{array}$ \\
\hline $\begin{array}{l}\text { Chemical } \\
\text { input }\end{array}$ & $\begin{array}{l}\text { Urea } \\
\text { Pesticides } \\
\text { (organophosphates) }\end{array}$ & $\begin{array}{l}321.8 \mathrm{ton} \\
53 \mathrm{~kg}\end{array}$ \\
\hline \multirow{2}{*}{ Material input } & Groundwater & $\begin{array}{l}6,765,000 \\
\mathrm{~m}^{3}\end{array}$ \\
& Kenaf seed & $\begin{array}{l}12.177 \\
\text { tons }\end{array}$ \\
\hline \multirow{2}{*}{ Transportation } & Truck & $\begin{array}{l}27.000 \\
\text { tkm } \\
\end{array}$ \\
& Solar & $1.700 \mathrm{~kg}$ \\
\hline
\end{tabular}

The value of the environmental impact comes from the characterization impact assessment, normalization impact assessment, and network assessment. The relationship of each material use process that results in environmental impacts can be seen from the network. On a system, two-color lines symbolize specific meanings. The red lines show that the process influences the ecological impact. Green lines indicate that the process does not affect ecological impacts. The network picture of the kenaf aquaculture environmental impact is presented in Fig. 2. The network results illustrate that the two factors are red-striped, which means that the kenaf aquaculture activity, especially the use of its material, affects the environment. The use of urea fertilizer has the most significant environmental impact, and this can be seen from the thickest red line. The fertilizer composition that contributes to the most significant influence is the chemical ammonia. The use of fertilizer cannot 


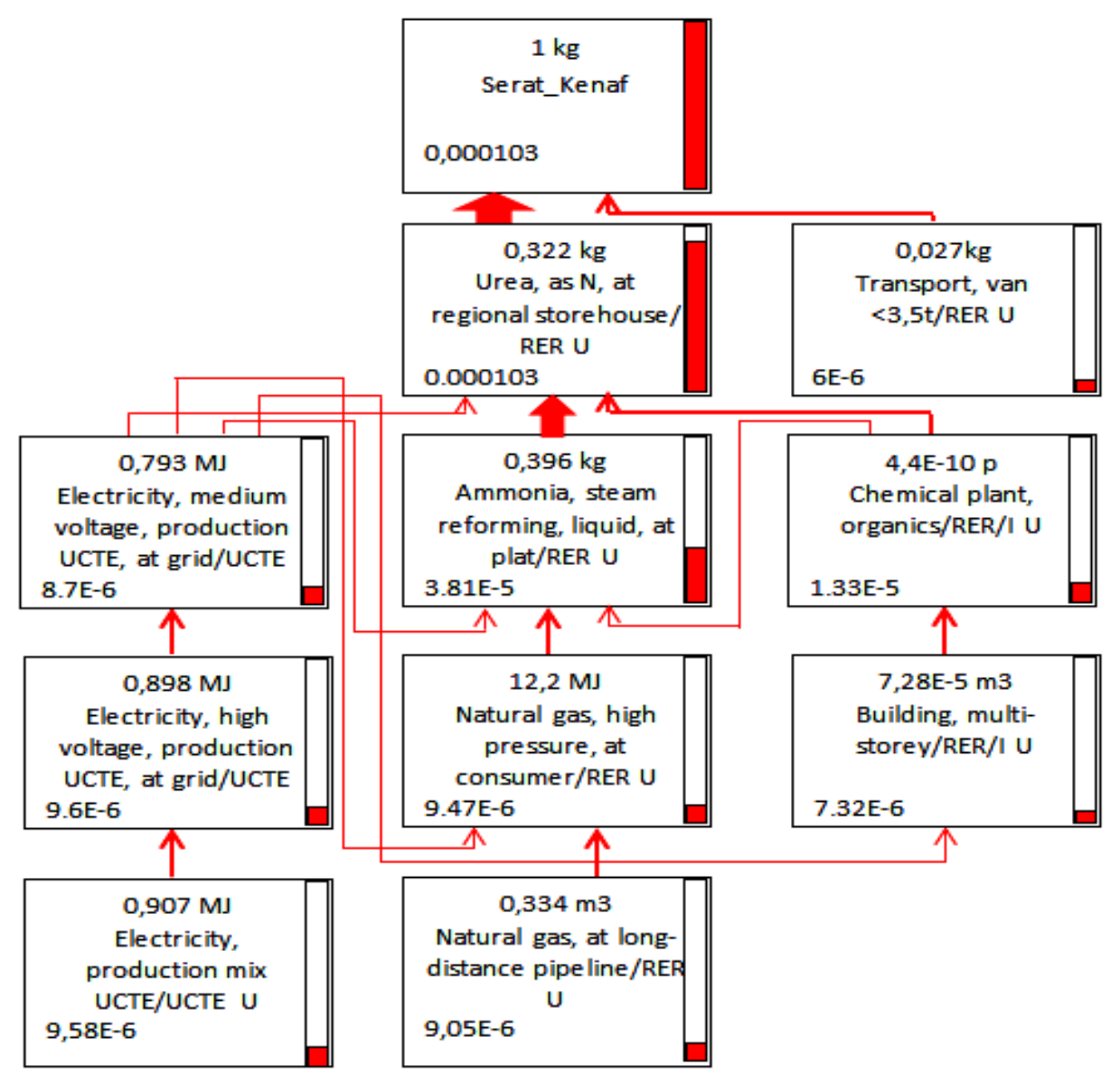

Fig. 2. Kenaf cultivation network

plantation activities. The problem in developing kenaf in Indonesia is the level of competition with other commodities to obtain fertile land so that kenaf is directed to less potential land. This makes kenaf farmers must use urea in maintaining and increasing the yield of kenaf fiber. The use of transportation for shipping to the collecting area has a second environmental impact.

The next step is to determine the environmental impact of each use of materials and chemicals. The category of each environmental impact follows the Impact 2002+ method. The 2002+ Impact method consists of fifteen impact categories. The fifteen impact categories are grouped into four groups, namely:

1. Resources: non-renewable energy, mineral extraction.

2. Climate change: global warming.

3. Ecosystem quality: aquatic ecotoxicity, terrestrial ecotoxicity, aquatic acidification, aquatic eutrophication, terrestrial acid/nutri, land occupation.

4. Human health: carcinogens, respiratory inorganics, respiratory organics ionizing radiation, ozone layer depletion, noncarcinogens.

The acquisition value of the fifteen impact categories is presented in Table 2 . From $1 \mathrm{~kg}$ of kenaf fiber harvested, the most significant environmental impact caused was in the aquatic ecotoxicity category, amounting to $42.1 \mathrm{~kg}$ TEG water. The high value of aquatic ecotoxicity is due to the use of urea. The aluminum content of urea pollutes the soil, air, and water. The lowest environmental impact category is the ozone layer depletion, 1.72E-7 kg CFC-11 eq.

The next calculation is the normalization stage. This stage aims to facilitate the comparison between impact categories and show the contribution of impact categories to environmental problems in an area. Impact 
category values use the same unit. Normalization results are presented in Table 3 .

Table 2. Impact characterization for $1 \mathrm{~kg}$ of kenaf fiber

\begin{tabular}{lcc}
\hline Impact category & Unit & Total \\
\hline Carcinogens & $\mathrm{kg} \mathrm{C} 2 \mathrm{H} 3 \mathrm{Cl}$ eq & 0.0146 \\
$\begin{array}{l}\text { Non-carcinogens } \\
\text { Respiratory }\end{array}$ & $\mathrm{kg} \mathrm{C2H3Cl} \mathrm{eq}$ & 0.00951 \\
$\begin{array}{l}\text { inorganics } \\
\text { Ionizing radiation }\end{array}$ & $\mathrm{kq} \mathrm{PM} 2.5 \mathrm{eq}$ & 0.000948 \\
$\begin{array}{l}\text { Ozone layer } \\
\text { depletion }\end{array}$ & $\mathrm{kg} \mathrm{CFC}-11 \mathrm{eq}$ & $1.72 \mathrm{E}-7$ \\
$\begin{array}{l}\text { Respiratory } \\
\text { organics }\end{array}$ & $\mathrm{kg} \mathrm{C} 2 \mathrm{H} 4 \mathrm{eq}$ & 0.000306 \\
$\begin{array}{l}\text { Aquatic } \\
\text { ecotoxicity }\end{array}$ & $\mathrm{kg} \mathrm{TEG} \mathrm{water}$ & 42.1 \\
$\begin{array}{l}\text { Terrestrial } \\
\text { ecotoxicity }\end{array}$ & $\mathrm{kg} \mathrm{TEG} \mathrm{soil}$ & 13.4 \\
$\begin{array}{l}\text { Terrestrial } \\
\text { acid/nutri }\end{array}$ & $\mathrm{kg} \mathrm{SO} 2 \mathrm{eq}$ & 0.027 \\
$\begin{array}{l}\text { Land occupation } \\
\text { Aquatic } \\
\text { acidification }\end{array}$ & $\mathrm{M} 2 \mathrm{org}$. arable & 0.0192 \\
$\begin{array}{l}\text { Aquatic } \\
\text { eutrophication }\end{array}$ & $\mathrm{kg} \mathrm{SO} 2$ eq & 0.00471 \\
$\begin{array}{l}\text { Global warming } \\
\text { Non-renewable } \\
\text { energy }\end{array}$ & $\mathrm{kg} \mathrm{CO} 2$ eq & 1,1 \\
$\begin{array}{l}\text { Mineral } \\
\text { extraction }\end{array}$ & $\mathrm{MJ}$ primary & 23.3 \\
\hline
\end{tabular}

Normalization calculation results for each group of impact categories are as follows:

a. Resources (non-renewable energy dan mineral extraction)
The resource impact category has the highest environmental impact value of 0.000153 . The environmental impact is due to the use of urea fertilizer during the kenaf cultivation period. This is because the process of making urea fertilizer requires quite large electrical energy. Using electricity is the same as using natural gas and fossil fuels, non-renewable energy.

b. Climate change (global warming)

The second-largest category of impact is climate change of 0.000111 . Climate change is the second-highest recipient of the effects because the value of global warming is quite high. The use of urea fertilizer is a contributor to global warming. In the process, urea fertilizer produces carbon dioxide, methane, and carbon monoxide. These compounds are contributors to global warming.

c. Human health (carcinogens, respiratory inorganics, ionizing radiation, ozone layer depletion, non-carcinogens)

The third-largest category of impact is human health by 0.000103 . The use of urea fertilizer is the most significant contributor to human health impacts. This is because the urea particle factor is quite small $(<2.5 \mu \mathrm{m})$. The urea content of nitrogen oxides, ammonia, and sulfur dioxide also causes health problems.

d. Ecosystem quality (aquatic ecotoxicity, terrestrial ecotoxicity, aquatic acidification, aquatic eutrophication, terrestrial acid/nutri, land occupation)

The category of ecosystem quality impacts is the lowest impact of kenaf aquaculture activities, amounting to $1.15 \mathrm{E}-5$. Even though the value is the most economical, kenaf cultivation activities still have an effect on the quality of the ecosystem.

Table 3. The impact of normalization categories in kenaf cultivation

\begin{tabular}{lcccccc}
\hline \multicolumn{1}{c}{$\begin{array}{c}\text { Impact } \\
\text { category }\end{array}$} & Total & Cotton seed & Urea & Organophosphate & Truck & Diesel \\
\hline $\begin{array}{l}\text { Human health } \\
\text { Ecosystem }\end{array}$ & $1.03 \mathrm{E}-4$ & $1.17 \mathrm{E}-6$ & $9.61 \mathrm{E}-5$ & $3.74 \mathrm{E}-8$ & $6 \mathrm{E}-6$ & $1.34 \mathrm{E}-7$ \\
$\begin{array}{l}\text { quality } \\
\begin{array}{l}\text { Clinmate } \\
\text { change }\end{array}\end{array}$ & $1.15 \mathrm{E}-5$ & $1.31 \mathrm{E}-6$ & $9.34 \mathrm{E}-6$ & $5.92 \mathrm{E}-9$ & $7.8 \mathrm{E}-7$ & $3.32 \mathrm{E}-8$ \\
Resources & $1.11 \mathrm{E}-4$ & $3.48 \mathrm{E}-7$ & $1.05 \mathrm{E}-4$ & $3.99 \mathrm{E}-8$ & $5.2 \mathrm{E}-6$ & $8.18 \mathrm{E}-8$ \\
\hline
\end{tabular}


The results of characterization and normalization output show that overall kenaf cultivation has an impact on the environment. The most significant environmental impact is caused by the use of urea fertilizer (1.46 E-4). The type of soil in kenaf cultivation is sandy loam. Fertilization for kenaf cultivation adheres to a balanced fertilization system, namely the provision of nutrients adjusted to the needs of plants and the level of soil fertility. The $\mathrm{N}$ and $\mathrm{P}$ elements, especially the $\mathrm{N}$ elements in kenaf planting land, are still lacking. Kenaf plants are in dire need of $\mathrm{N}$-fertilization because what is harvested is the stem [24]. One effort to improve soil fertility, especially adding element $\mathrm{N}$ in cultivated land, is to add urea fertilizer. Seeing the adverse effects of using urea fertilizer, we need a way to reduce the use of urea fertilizer. One way is to use organic fertilizer. Some studies suggest that organic fertilizer affects soil fertility, especially in kenaf cultivation. Organic fertilizers can release slow nutrients, have a high adsorption capacity, and reduce the activity of aluminum ( $\mathrm{Al})$ so that it can increase the phosphate element $(\mathrm{P})$ [25], [26], and [27].

\section{CONCLUSION}

Based on the results of the analysis with LCA, the most significant environmental impact of kenaf cultivation in Bonorowo Land, Laren is aquatic ecotoxicity (42.1 kg TEG water). The most significant environmental impact group is resources (1.53 E-4). The environmental impact is caused by the use of urea (1.46 E-4). The process of making urea requires considerable electrical energy, and it affects the use of non-renewable energy. The use of urea produces aluminum elements that pollute the air, water, and soil. This research is only on the analysis of environmental impacts. This research can be continued with the selection and application of improvements from kenaf cultivation activities to reduce the environmental impact caused.

\section{REFERENCES}

[1] S. Wibowo, "Budidaya Kenaf," in Lembar Informasi Pertanian, Loka Pengkajian Teknologi Pertanian Samarinda, Departemen Pertanian, 2000, available at: http://203.190.36.42/agritek/lip50097.pdf.

[2] R. D. Purwati, "Plasma nutfah kenaf (Hibiscus cannabinus L.)," Monogr.
Balittas, vol. 1, no. 2, pp. 13-26, 2009, available at: http://balittas.litbang.pertanian.go.id/imag es/Monograf/plasma nutfah kenaf.pdf.

[3] M. N. Haryono, H. Syahbuddin, and M. Sarwani, Lahan Rawa, Penelitian dan Pengembangan. Kementerian Pertanian: Badan Penelitian dan Pengembangan Pertanian, 2013, available at: http://bbsdlp.litbang.pertanian.go.id/ind/in dex.php/publikasi-

3/buku?download=6:lahan-rawapenelitian-dan-pengembangan-pertanian.

[4] D. K. Maheshwari, S. Dheeman, and M. Agarwal, "Decomposition of Organic Materials into High Value Compost for Sustainable Crop Productivity," in Composting for Sustainable Agriculture, Springer, 2014, pp. 245-267, doi: 10.1007/978-3-319-08004-8_12.

[5] C. Thonar et al., "Potential of three microbial bio-effectors to promote maize growth and nutrient acquisition from alternative phosphorous fertilizers in contrasting soils," Chem. Biol. Technol. Agric., vol. 4, no. 1, p. 7, Dec. 2017, doi: 10.1186/s40538-017-0088-6.

[6] Z. Cheng, E. L. McCoy, and P. S. Grewal, "Water, sediment, and nutrient runoff from urban lawns established on disturbed subsoil or topsoil and managed with inorganic or organic fertilizers," Urban Ecosyst., vol. 17, no. 1, pp. 277-289, Mar. 2014, doi: 10.1007/s11252-013-0300-9.

[7] S. Huang, L. Wang, L. Liu, Q. Fu, and D. Zhu, "Nonchemical pest control in China rice: a review," Agron. Sustain. Dev., vol. 34, no. 2, pp. 275-291, Apr. 2014, doi: 10.1007/s13593-013-0199-9.

[8] R. Salomone, G. Saija, G. Mondello, A. Giannetto, S. Fasulo, and D. Savastano, "Environmental impact of food waste bioconversion by insects: Application of Life Cycle Assessment to process using Hermetia illucens," J. Clean. Prod., vol. 140, pp. 890-905, Jan. 2017, doi: 10.1016/j.jclepro.2016.06.154.

[9] C. Chai, "Life Cycle Assessment: An Intoduction to Concepts and Applications," AZoCleantech, pp. 1-4, 2014, available at: https://www.azocleantech.com/article.asp 
$\mathrm{x}$ ?ArticleID $=516$.

[10] A. Nikkhah, M. Khojastehpour, B. Emadi, A. Taheri-Rad, and S. Khorramdel, "Environmental impacts of peanut production system using life cycle assessment methodology," J. Clean. Prod., vol. 92, pp. 84-90, Apr. 2015, doi: 10.1016/j.jclepro.2014.12.048.

[11] M. F. Astudillo, G. Thalwitz, and F. Vollrath, "Modern analysis of an ancient integrated farming arrangement: life cycle assessment of a mulberry dyke and pond system," Int. J. Life Cycle Assess., vol. 20, no. 10 , pp. 1387-1398, Oct. 2015, doi: 10.1007/s11367-015-0950-3.

[12] A. Nikkhah, "Life cycle assessment of the agricultural sector in Iran (2007-2014)," Environ. Prog. Sustain. Energy, vol. 37, no. 5, pp. 1750-1757, Sep. 2018, doi: 10.1002/ep.12831.

[13] P. Goglio et al., "Development of Crop.LCA, an adaptable screening life cycle assessment tool for agricultural systems: A Canadian scenario assessment," J. Clean. Prod., vol. 172, pp. 3770-3780, Jan. 2018, doi: 10.1016/j.jclepro.2017.06.175.

[14] M. J. Zarei, N. Kazemi, and A. Marzban, "Life cycle environmental impacts of cucumber and tomato production in openfield and greenhouse," J. Saudi Soc. Agric. Sci., vol. 18, no. 3, pp. 249-255, Jul. 2019, doi: 10.1016/j.jssas.2017.07.001.

[15] M. Tayefeh, S. M. Sadeghi, S. A. Noorhosseini, J. Bacenetti, and C. A. Damalas, "Environmental impact of rice production based on nitrogen fertilizer use," Environ. Sci. Pollut. Res., vol. 25, no. 16, pp. 15885-15895, Jun. 2018, doi: 10.1007/s11356-018-1788-6.

[16] C. Boland et al., "A Life Cycle Assessment of Natural Fiber Reinforced Composites in Automotive Applications," in Conference Proceeding 2014 SAE World Congress, 2015, pp. 179-189, doi: 10.4271/2014-011959.

[17] S. M. Batouli, Y. Zhu, M. Nar, and N. A. D'Souza, "Environmental performance of kenaf-fiber reinforced polyurethane: a life cycle assessment approach," J. Clean. Prod., vol. 66, pp. 164-173, Mar. 2014, doi: 10.1016/j.jclepro.2013.11.064.

[18] A. Nikkhah, S. Firouzi, M. El Haj Assad, and S. Ghnimi, "Application of analytic hierarchy process to develop a weighting scheme for life cycle assessment of agricultural production," Sci. Total Environ., vol. 665, pp. 538-545, May 2019 , doi: 10.1016/j.scitotenv.2019.02.170.

[19] M. M. Rahman and B. K. Bala, "Ecological and environmental sustatinability of jute production systems in Bangladesh: life cycle assessment.," SAARC J. Agric., vol. 7, no. 2, pp. 51-66, 2009, available at: https://www.cabdirect.org/cabdirect/abstra ct/20113126905.

[20] A. L. Fernando, "Environmental Aspects of Kenaf Production and Use, Kenaf: a multi-purpose crop for several industrial applications," in Green Energy and Technology, Springer, 2013, pp. 83-104, doi: 10.1007/978-1-4471-5067-1_5.

[21] O. Jolliet, H. Sébastien, A. D. Schryver, and M. Manuele, Impact 2002+: User Guide. Switzerland: Swiss Federal Institute of Technology Lausanne (EPFL), 2012, available at: https://www.quantisintl.com/pdf/IMPACT2002+_UserGuide_ for_vQ2.21_30April2014a.pdf.

[22] International Standards Organization, Environmental Management: Life Cycle Assessment; Principles and Framework. Principles and Framework ISO 14040, ISO Press, 2006, available at: https://www.iso.org/standard/37456.html.

[23] WHO-World Health Organization, "Pesticide residues in food-2000. Report of the Joint Meeting of the FAO Panel of Experts on Pesticide Residues in Food and the Environment and the WHO Core Assessment Group.," FAO Plant Production and Protection Paper, 163, 2001, available at: http://www.fao.org/fileadmin/templates/a gphome/documents/Pests_Pesticides/JMP R/Reports_1991-2006/Report_2000.pdf.

[24] T. Ghosh, "Jute manual," Agric. Res. lost. Yesin. Burma, 1978, available at: Google Scholar.

[25] H. Pranoto, "Respons Pertumbuhan dan Kualitas Beberapa Varietas Kenaf (Hibiscus Cannabinus L.) terhadap Pemberian Pupuk N dan Kotoran Ayam," Ziraa'ah Maj. Ilm. Pertan., vol. 41, no. 1, 
pp. 27-32, 2016, available at: https://ojs.uniska-

bjm.ac.id/index.php/ziraah/article/view/31 7.

[26] Rusmini, R. R. Manullang, and Daryono, "Peningkatan Produksi Serat Kenaf Dengan Pemberian Pupuk Organik Kompos Kulit Udang Dan Pestisida Nabati Keong Mas," in Prosiding Seminar Nasional Ke 1 Tahun 2017, 2017, pp. 4655, available at: https://baristandsamarinda.kemenperin.go. id/download/proceeding/2017_semnas1/H al_46-55_Ok.pdf.

[27] B. Santoso, "Pengaruh bahan organik dan pupuk NPK terhadap hasil serat rosela di lahan podsolik merah kuning Kalimantan Selatan," J. Penelit. Tanam. Ind., vol. 11, no. 3, pp. 85-92, 2005, available at: http://repository.pertanian.go.id/handle/12 $3456789 / 1582$. 